\title{
Geochemical distribution of trace metal pollutants in water and sediments of downstream of an urban river
}

\author{
${ }^{1,2 *}$ K. M. Mohiuddin; ${ }^{2}$ H. M. Zakir; ${ }^{1}$ K. Otomo; ${ }^{1}$ S. Sharmin; ${ }^{1}$ N. Shikazono \\ ${ }^{1}$ Laboratory of Geochemistry, School of Science for Open and Environmental Systems, Faculty of Science and \\ Technology, Keio University, Hiyoshi 3-14-1, Yokohama, Japan \\ ${ }^{2}$ Department of Agricultural Chemistry, Bangladesh Agricultural University, Mymensingh, Bangladesh
}

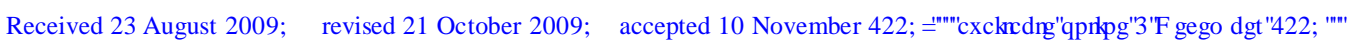

\begin{abstract}
A study was conducted to investigate the trace metal pollution of water and sediments of downstream of Tsurumi River, Yokohama, Japan. Twenty samples of water and sediments were collected from the river starting from Tokyo bay side up to the junction point of the Yagami River. Results show that the mean concentrations of chromium, cupper and nickel in water greatly exceed ( $>100$ times) the surface water standard. The concentration of molybdenum and lead was also higher than standard values while iron and manganese was lower than that of surface water standard. The mean concentration of zinc, cupper, cadmium, lead, chromium, vanadium, bromine and iodine was 381.1, 133.0, 1.0, 40.8, 102.9, 162.0, 71.5 and $10.6 \mu \mathrm{g} / \mathrm{g}$ sediments, respectively and was greatly exceed the average worldwide shale concentrations and average Japanese river sediment values. However, mean concentration of arsenic, nickel and strontium was $11.0,36.6$ and $164.6 \mu \mathrm{g} / \mathrm{g}$ sediments, respectively which was lower than the average shale value. Other analyzed trace metals, including barium, zirconium, rubidium, yttrium, tin, antimony, cesium, lanthanum, cerium, praseodymium and neodymium were detected in river sediments; the concentration of which was close to the Japan's river sediment average values. Pollution load index values of the sites of the studied area ranged from 1.24 to 7.65 which testify that the river sediments are polluted. The PLI value of the area was, however, high (6.53) as the concentration of trace metals like zinc, cupper, cadmium, lead and chromium were very high and were the major pollutants.
\end{abstract}

Keywords: Enrichment factors; Environmental pollution; Heavy metal; Pollution load index; Tsurumi river; Water quality and River-bed sediments

\section{INTRODUCTION}

Trace metals are among the most common environmental pollutants and their occurrence in waters and biota indicate the presence of natural or anthropogenic sources. The existence of trace metals in aquatic environments has led to serious concerns about their influence on plant and animal life (Sheikh et al., 2007; Zvinowanda et al., 2009). Metal nutritional requirements differ substantially between species or elements and optimum ranges of concentrations are generallynarrow. Severe imbalances on metal proportions caused by exposure to elevated concentrations can induce death even of organisms (Agbozu et al., 2007). Elements like $\mathrm{Pb}$, Cd, As etc. exhibit extreme toxicity even at trace levels (Nicolau et al., 2006). Rivers are a dominant pathway for metals transport (Miller et al., 2003) and trace metals may become significant pollutants of many small riverine systems (Dassenakis et al., 1998). The

*Corresponding Author Email: mohiagchem@gmail.com Tel.: +81 0906522 0786; Fax: +81045 5661551 behaviour of metals in natural waters is a function of the substrate sediment composition, the suspended sediment composition and the water chemistry (Osmond et al., 1995; Shrestha et al., 2007; Harikumar et al., 2009). During their transport, the trace metals undergo numerous changes in their speciation due to dissolution, precipitation, sorption and complexation phenomena (Akcay et al., 2003; Abdel-Ghani et al., 2007; AbdelGhani and Elchaghaby, 2007) which affect their behaviour and bioavailability. Recent studies reveal that the accumulation and distribution of hydrocarbons, trace metals and chlorinated compounds in soil, water and environment are increasing at an alarming rate causing deposition and sedimentation in water reservoirs and affecting aquatic organisms, as well (Hobbelen et al., 2004). The list of sites contaminated with trace metals grows every year, presenting a serious problem for human health and a fearful danger to the environment (Marin et al., 2001). Water of the Tsurumi has been receiving 
significant amount of wastes containing base metals from municipal wastewaters, household garbage, industrial and vehicle discharges due to rapid urbanization and strong wildlife populations, consequently the quality of water is being polluted. Keeping these views in mind, this research work was conducted to determine the extent of trace metal content in water and sediments of the downstream of the polluted Tsurumi River, Yokohama, Japan and compare its level with geochemical background and toxicological reference values for river sediments, as well as to assess the extent of anthropogenic pollution in its sediments. This study was carried out in 2008 - 2009 in the Laboratory of geochemistry, Keio University, Yokohama, Japan.

\section{Description of the study area}

The Tsurumi River flows from its source in Machida city down to Tokyo Bay at the river mouth of Tsurumi Ward, Yokohama (Fig. 1). It flows $42.5 \mathrm{~km}$ through Machida city, Yokohama City, and Kawasaki city, the river basin area of which is $235 \mathrm{~km}^{2}$. The basin of the Tsurumi River is regarded as one of the most important and representative river basins in Japan. The basin was largely developed by the rapid urbanization since 1960s. The transition of the urban area increased from $10 \%$ (1958) to over $84 \%$ in late 2000 . The total population in the basin reached about 1.9 million in 2004 the density being 8,000 people $/ \mathrm{km}^{2}$. The inland manufacturing district is located in the river basin. Moreover, open - air industrial waste incineration has been performed on the river at Shin- Yokohama area (Nito et al., 2003). The area mainly consists of Tertiary and Quaternary sedimentary rocks (shale and sandstone) overlain by Quaternary volcanic materials and weathered soils of volcanic origin. Alluvium sediments consisting of various kinds of rock fragments (granite, basalt, chert, limestone, shale, sandstone) were derived from upper stream region where Paleozoic rocks are distributed (Omori etal., 1986).

\section{MATERIALS AND METHODS}

\section{Sediment and water sampling}

Twenty sampling sites were chosen for collection of water and sediments from the Tsurumi River downstream, starting from Tokyo bay side up to the junction point of theYagami River (Table 1 and Fig. 1). Water and sediment samples were collected on October 8, 2008. Surface sediment samples were taken at a depth of $0-10 \mathrm{~cm}$ which were quickly packed in air tight polythene bags. Subsamples of the material were oven dried at $45^{\circ} \mathrm{C}$ for $48 \mathrm{~h}$ and ground using mortar and pestle. Then the samples were sieved by a sieve (aperture $125 \mu \mathrm{m}$ ). The lower particle size fraction was homogenized by grinding in an agate mortar and stored in glass bottles until chemical analyses were carried out and marked well. Precautions were taken to avoid contamination during drying, grinding, sieving

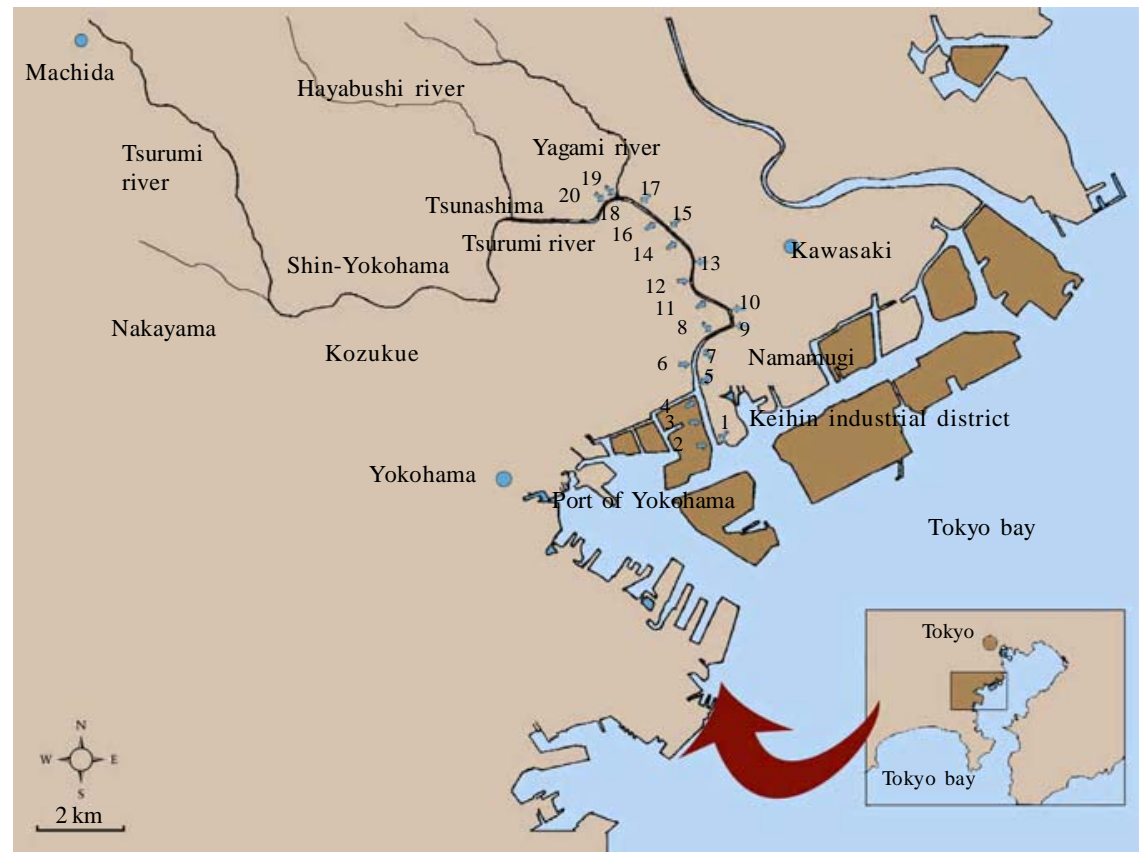

Fig. 1: The location of sampling sites at downstream of Tsurumi River, Yokohama, Japan 
Table 1: Location of different sampling sites of the downstream of the Tsurumi River, Japan

\begin{tabular}{cl}
\hline Sample No. & \multicolumn{1}{c}{ Location } \\
\hline 1 & Tokyo power station \\
2 & Toshiba factory \\
3 & Nissan motor factory \\
4 & JFE \\
5 & Daikoku canal \\
6 & Tsurumi big bridge \\
7 & Tsurumi line \\
8 & Shiomi bridge \\
9 & Shiotsuru bridge \\
10 & Ashiho bridge \\
11 & Right side of Tsurumi bridge \\
12 & Left side of Tsurumi bridge \\
13 & Tsurumi river bridge \\
14 & Nothern No. 1 sluitch gate \\
15 & New Tsurumi bridge \\
16 & Suidokan bridge \\
17 & Egasaki pumping place \\
18 & Sueyoshi bridge \\
19 & Takano big bridge \\
20 & Jindou bridge \\
\hline
\end{tabular}

and storage. Water samples from the same points were also collected and transferred into acid-cleaned $100 \mathrm{~mL}$ polypropylene bottles. $2 \mathrm{~mL}$ of ultrapure nitric acid was added in each polypropylene bottle to achieve the $\mathrm{pH}$ of $\sim 1$ (Cenci and Martin, 2004). All chemicals and reagents were of analytical reagent grade quality (Sigma-Aldrich, USA and Wako, Japan). Millipore water was used throughout all the experiments. Before use, all glass and plastic ware were soaked in $14 \% \mathrm{HNO}_{3}$ for $24 \mathrm{~h}$. The washing was completed with Millipore water rinse.

\section{Analysis of water and sediments}

The $\mathrm{pH}$, electrical conductivity (EC), oxidation reduction potential (ORP) values and dissolve oxygen (DO) content of water samples were measured during sampling and cations and anions in water samples were measured using atomic absorption spectrophotometer (AAS) and ion chromatography (IC). The pH of sediments was measured in 1:2.5 sediment to water ratio. The suspension was allowed to stand overnight prior to $\mathrm{pH}$ determination. EC was measured in saturation extract of sediments using an EC meter. Particle size of sediments was measured by using a laser scattering particle size distribution Aanalyzer (Horiba: LA-920, Kyoto, Japan) following the manufacturer's recommendations and textural classes were selected using texture autolookup (TAL) 4.2 software following the USDA system and organic carbon (OC) was measured by the wet oxidation method of Walkley and Black(1934). For the determination of total trace metals (e.g. Zn, $\mathrm{Cu}, \mathrm{Cd}, \mathrm{Pb}, \mathrm{Cr}, \mathrm{Ni}$ and $\mathrm{Sr}$ ) the extraction was carried out in Teflon containers provided with screw stoppers as described by Tessier et al. (1979) and trace metals concentrations in the extract were determined by a Hewlett-Packard (HP 4500, USA) ICPMS at National Institute of Advanced Industrial Science and Technology (AIST), Tsukuba, Japan. The total concentration of other trace metals (e.g. V, Br, I, As, Ba, Zr, Rb, Y, Sn, Sb, Cs, La, Ce, Pr and Nd) of sediment samples were measured by X-Ray Fluorescence Spectroscopy, employing a Rigaku RIX 1000 (Tokyo, Japan) XRF; using powder pellet samples. Filtered water samples were also analyzed for the some trace metals using inductively coupled plasma-atomic emission spectroscopy(ICP-AES) as described by APHA (1998). All the reagents and chemicals used were of analytical grade.

\section{Determination of enrichment factor}

To evaluate the magnitude of contaminants in the environment, the enrichment factors $\left(\mathrm{EF}_{\mathrm{c}}\right)$ were computed relative to the abundance of species in source material to that found in the Earth's crust and following equation was used to calculate the EFc as proposed by Atgin et al. (2000).

$E F C=\left(C_{M} / C_{A}\right)_{\text {sample }} /\left(C_{M} / C_{A}\right)_{\text {Earth's crust }}$

Where, $\left(\mathrm{C}_{\mathrm{M}} / \mathrm{C}_{\mathrm{Al}}\right)_{\text {sample }}$ is the ratio of concentration of trace metal $\left(\mathrm{C}_{\mathrm{M}}\right)$ to that of $\mathrm{Al}\left(\mathrm{C}_{\mathrm{Al}}\right)$ in the sediment sample and $\left(\mathrm{C}_{\mathrm{M}} / \mathrm{C}_{\mathrm{Al}}\right)_{\text {Earth's crust }}$ is the same reference ratio in the Earth's crust. The average abundance of $\mathrm{Zn}, \mathrm{Cu}, \mathrm{Cd}, \mathrm{Pb}$, Cr, As and $\mathrm{Ni}$ (70, 55, 0.2, 12.5, 100, 1.8 and $75 \mu \mathrm{g} / \mathrm{g}$, respectively) in the reference Earth's crust were taken from Huheey (1983) and $\mathrm{Al}$ (the reference value being 7.8 $\%$ ) was selected as the reference element, due to its crustal dominance and its high immobility.

\section{Determination of geoaccumulation index}

The geoaccumulation index $I_{\text {geo }}$ values were calculated for different metals as introduced by Muller (1969) is as follows:

$I_{\text {geo }}=\log _{2}\left(\frac{C_{n}}{1.5 \times B_{n}}\right)$

Where, $C_{n}$ is the measured concentration of element $n$ in the sediment and $\mathrm{B}_{\mathrm{n}}$ is the geochemical background for the element $n$ which is either directly measured in precivilization sediments of the area or taken from the literature (average shale value described by Turekian and Wedepohl, 1961). The factor 1.5 is introduced to include possible variations of the background values 
that are due to lithologic variations. Muller, (1981) proposed seven grades or classes of the geoaccumulation index. Class 0 (practically uncontaminated): $I_{\text {geo }}<0$ Class 1 (uncontaminated to moderately contaminated): $0<I_{g e o}<1$; Class 2 (moderately contaminated): $0<I_{\text {geo }}<2$; Class 3 (moderately to heavily contaminated): $2<I_{\text {geo }}<3$; Class 4 (heavily contaminated): $3<I_{\text {geo }}<4$; Class 5 (heavily to extremely contaminated): $4<I_{g e o}<5$; Class 6 (extremely contaminated): $5<I_{g e o}$. Class 6 is an open class and comprises all values of the index higher than Class 5. The elemental concentrations in Class 6 may be hundred fold greater than the geochemical background value.

\section{Assessment of pollution load index}

The pollution load index (PLI) proposed by Tomlinson et al. (1980) has been used in this study to measure PLI in sediments of Tsurumi River. The PLI for a single site is the $n$th root of $n$ number multiplying the contamination factors (CF values) together. The CF is the quotient obtained as follows:

$\mathrm{CF}=\mathrm{C}_{\text {Metal concentration }} / \mathrm{C}_{\text {Background concentration of the same metal }}$ and
$P L I$ for a site $=n t h \sqrt{C F_{1} \times C F_{2} \ldots \times C F_{n}}$

Such site indices can be treated in exactly the same way to give a zone or area index. Therefore,

PLI for a zone $=n$th $\sqrt{\text { site }_{1} \times \text { site }_{2} \ldots \times \text { site }_{n}}$

where $n$ equals the number of contamination factors and sites, respectively.

\section{RESULTS AND DISCUSSION}

Extent of contamination of water with trace metals

The analyzed physic-chemical parameters of water of the Tsurumi River are presented in Table 2. The pHvalue ranged from 7.43 to 8.03 with a mean value of 7.67 , which was within the recommended range for drinking water quality standard prescribed by US EPA (1989). The mean EC, ORP and DO values were $3.08 \mathrm{Sm}^{-1} 120 \mathrm{mV}$ and 6.528 $\mathrm{mg} / \mathrm{L}$, respectively. The mean concentration of $\mathrm{Na}^{+}, \mathrm{K}^{+}$, $\mathrm{Ca}^{2+}, \mathrm{Mg}^{2+}, \mathrm{F}^{-}, \mathrm{Cl}^{-}, \mathrm{Br}^{-}$and $\mathrm{SO}_{4}^{2-}$ were 5.62, 0.26, 0.30, $0.67,0.91,12.99,0.05$ and $1.20 \mathrm{~g} / \mathrm{L}$, respectively. These cations and anions showed decreasing trend from Tokyo bay side to upper side of the river and cation content was around thousand times higher than surface water standard but lower than the sea water standard. This might be due to mixing the downstream water of the Tsurumi River with sea water by tidal flow. Trace metal concentration in different sampling sites of the downstream of the Tsurumi River and their comparison with different surface water standards have been presented in Table 3. The mean concentrations of Cr, $\mathrm{Cu}, \mathrm{Fe}, \mathrm{Mo}, \mathrm{Mn}, \mathrm{Ni}$ and $\mathrm{Pb}$ in all studied water samples were $0.104,0.510,0.241,0.260,0.061,0.139$ and $0.038 \mu \mathrm{g} /$ $\mathrm{mL}$, respectively. The mean concentration of $\mathrm{Cr}$, $\mathrm{Cu}$ and Ni greatly exceed ( $>100$ times) the surface water standard. The contents of $\mathrm{Mo}$ and $\mathrm{Pb}$ were also higher than standard values but Fe and Mn were lower than that of surface water standard. Islam et al. (2000) emphasized that the largest portion of trace elements such as As, Cr, $\mathrm{Ni}, \mathrm{Zn}$ etc. dissolved in natural water systems is usually tied up primarily in two forms- as weathered solids of precipitates and adsorbed on the surfaces of particulate material, such as organic debris or clay. Pollutants accumulated in sediments can return to waters in suspended or dissolved form and pose a potential risk for aquatic environment (Zakir et al., 2006).

\section{General characteristics of sediments}

The mean value of $\mathrm{pH}, \mathrm{EC}$ and \% OC of sediment samples were 7.81, 0.646/Sm and 6.5 respectively (Table 4). The value of $\mathrm{pH}, \mathrm{EC}$ and \% OC in sediment samples of the Tsurumi River showed a decreasing trend from Tokyo bay side to upper side. Organic carbon in sediment samples was, in general high and its content reached the highest value at positions 1, 6 and 10 (6.3, 6.2 and $6.5 \%$, respectively). Samples of upper stream especially at sampling positions 17 to 20 showed the lower values of $\mathrm{pH}, \mathrm{EC}$ and \% OC. Table 4 also represents the particle size distribution of sediment samples where, sample 6 was clay and the sample 1 have clay loam- like textures. Samples 2, 4, 5, 7, 13 and 17 have loamy- like textures and the others were sandy clay loams, sandy loam or loamy sand - like textures. Horowitz (1991) reported that trace metal concentration showed a general increase in clay minerals content and a decrease in the quartz content in the sediments. This author further stated that fine silt and clay fractions were good enough to accumulate higher quantities of trace metals in the sediment which is concomitant with present findings.

\section{Concentrations of trace metals in sediments}

The range and mean of total $\mathrm{Zn}, \mathrm{Cu}, \mathrm{Cd}, \mathrm{Pb}, \mathrm{Cr}, \mathrm{V}, \mathrm{Br}, \mathrm{I}$, As, Ni and $\mathrm{Sr}$ contents in sediments are presented in Table 5a. The mean concentration of $\mathrm{Zn}, \mathrm{Cu}, \mathrm{Cd}, \mathrm{Pb}, \mathrm{Cr}, \mathrm{V}$, $\mathrm{Br}$ and $\mathrm{I}(381.1,133.0,1.0,40.8,102.9,162.0,71.5$ and 10.6 
Int. J. Environ. Sci. Tech., 7 (1), 17-28, Winter 2010

Table 2: Physico-chemical properties, cation and anion concentration in water samples of Tsurumi River, Japan

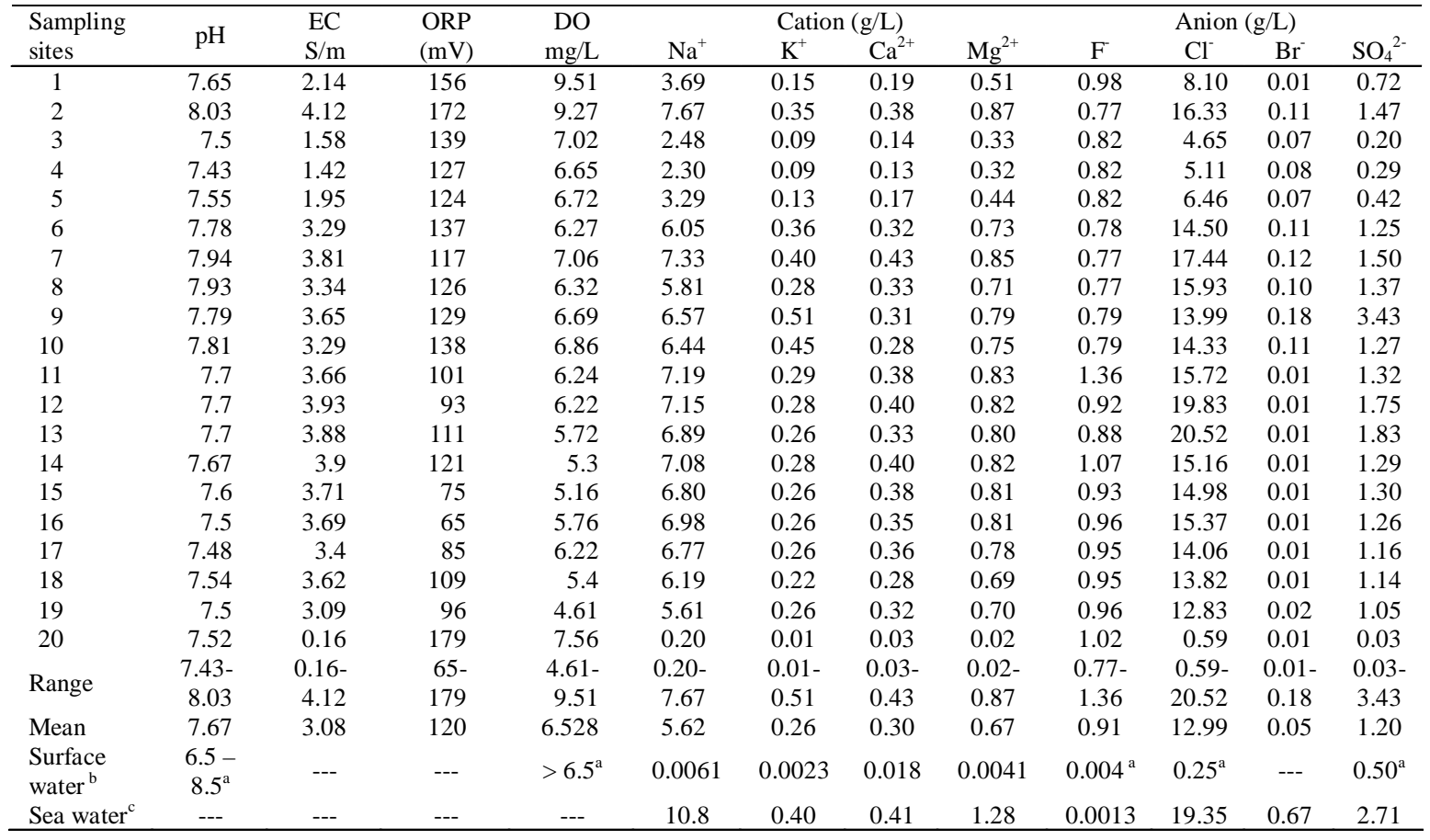

a, b, c Standard values taken from US EPA (1989) for drinking water, Wedepohl (1969-1979) for surface water and Millero (1974) for sea water, respectively

Table 3: Trace metal concentration $(\mu \mathrm{g} / \mathrm{mL})$ in waters of Tsurumi River, Japan

\begin{tabular}{|c|c|c|c|c|c|c|c|}
\hline \multirow{2}{*}{ Sampling sites } & \multicolumn{7}{|c|}{ Trace metals (concentration in $\mu \mathrm{g} / \mathrm{mL}$ ) } \\
\hline & $\mathrm{Cr}$ & $\mathrm{Cu}$ & $\mathrm{Fe}$ & Mo & $\mathrm{Mn}$ & $\mathrm{Ni}$ & $\mathrm{Pb}$ \\
\hline 1 & 0.059 & 0.407 & 0.171 & 0.22 & BDL & 0.07 & BDL \\
\hline 2 & 0.071 & 0.419 & 0.199 & 0.269 & BDL & 0.09 & BDL \\
\hline 3 & 0.094 & 0.485 & 0.212 & 0.214 & BDL & 0.134 & BDL \\
\hline 4 & 0.089 & 0.443 & 0.193 & 0.194 & 0.009 & 0.113 & BDL \\
\hline 5 & 0.052 & 0.407 & 0.212 & 0.166 & BDL & 0.068 & 0.037 \\
\hline 6 & 0.217 & 0.568 & 0.362 & 0.38 & 0.131 & 0.223 & 0.339 \\
\hline 7 & 0.089 & 0.49 & 0.218 & 0.261 & BDL & 0.126 & 0.046 \\
\hline 8 & 0.086 & 0.436 & 0.217 & 0.218 & BDL & 0.1 & 0.083 \\
\hline 9 & 0.122 & 0.489 & 0.228 & 0.265 & BDL & 0.144 & BDL \\
\hline 10 & 0.135 & 0.549 & 0.267 & 0.281 & 0.027 & 0.159 & 0.048 \\
\hline 11 & 0.08 & 0.523 & 0.193 & 0.23 & 0.02 & 0.102 & BDL \\
\hline 12 & 0.111 & 0.467 & 0.226 & 0.236 & 0.027 & 0.14 & 0.023 \\
\hline 13 & 0.104 & 0.531 & 0.258 & 0.225 & 0.027 & 0.166 & 0.077 \\
\hline 14 & 0.1 & 0.577 & 0.272 & 0.313 & 0.039 & 0.16 & 0.036 \\
\hline 15 & 0.117 & 0.539 & 0.258 & 0.318 & 0.078 & 0.152 & 0.021 \\
\hline 16 & 0.126 & 0.625 & 0.292 & 0.358 & 0.194 & 0.187 & BDL \\
\hline 17 & 0.112 & 0.594 & 0.325 & 0.315 & 0.186 & 0.161 & BDL \\
\hline 18 & 0.141 & 0.654 & 0.27 & 0.303 & 0.211 & 0.2 & 0.049 \\
\hline 19 & 0.084 & 0.514 & 0.229 & 0.217 & 0.264 & 0.15 & BDL \\
\hline 20 & 0.083 & 0.489 & 0.226 & 0.216 & BDL & 0.128 & BDL \\
\hline Range & $0.052-$ & $0.407-$ & $0.171-$ & 0.166- & BDL - & $0.068-$ & BDL - \\
\hline Kange & 0.217 & 0.654 & 0.362 & 0.38 & 0.264 & 0.223 & 0.339 \\
\hline Mean & 0.104 & 0.510 & 0.241 & 0.260 & 0.061 & 0.139 & 0.038 \\
\hline Surface water standard & $0.0007^{\mathrm{a}}$ & $0.003^{\mathrm{a}}$ & - & $0.07^{\mathrm{b}}$ & $0.2^{\mathrm{b}}$ & $0.0003^{\mathrm{a}}$ & $0.01^{\mathrm{b}}$ \\
\hline Drinking water standard $^{\mathrm{c}}$ & 0.1 & 1.3 & 0.3 & - & 0.05 & 0.01 & 0.015 \\
\hline
\end{tabular}

BDL means Below Detectable Limit

a, b, c Standard values taken from Wedepohl (1969-1979), MOE - Japan (2004a) and US EPA (1989), respectively 
$\mu \mathrm{g} / \mathrm{g}$, respectively) greatly exceed the average concentration of these metals in shale as proposed by Turekian and Wedepohl (1961) and in Japan's river sediments (Table 7) as postulated by Gamo, (2007). Whereas mean concentration of As, $\mathrm{Ni}$ and $\mathrm{Sr}$ (11.0, 36.6 and $164.6 \mu \mathrm{g} / \mathrm{g}$, respectively) were lower than the average shale value. The highest concentration of total $\mathrm{Cu}, \mathrm{Cd}$, Pb, Cr, V, As and Ni (229.9, 5.7, 74.5, 252.7, 208.5, 21.7 and $57.5 \mu \mathrm{g} / \mathrm{g}$, respectively) were found in the sample at position 17. At sampling position 2 the content of I and $\mathrm{Sr}$ (21.5 and $265.9 \mu \mathrm{g} / \mathrm{g}$, respectively) was maximum. Zinc $(530.5 \mu \mathrm{g} / \mathrm{g})$ and $\mathrm{Br}(114.7 \mu \mathrm{g} / \mathrm{g})$ content was highest at sampling position 4 and 6 , respectively. The lowest concentration of all the trace metals except $\mathrm{Br}$ was observed at sampling position 18. The mean concentration of total $\mathrm{Zn}, \mathrm{Cu}, \mathrm{Cd}$ and I in sediments at downstream of the Tsurumi River was about four fold higher than the average shale value. Sorme and Lagerkvist (2002) identified domestic construction and car related source and untreated waste water as the main sources of Zn. High level of $\mathrm{Cu}$ indicate a higher input of organic matter deposition in these sites, which might come from urban and industrial wastes after sediment composition (Das and Nolting, 1993). Increasing Cd concentration might be related to industrial activity, atmospheric emission and deposition of organic and fine grain sediments (Khan et al., 1992). Other probable sources of Cd include leacheates from defused Ni-Cd batteries and Cd plated items
(Stoeppler, 1991). Pb is considered as a good indicator of pollution by urban run-off water. The use of leaded gasoline has been mainly responsible for the $\mathrm{Pb}$ pollution load during the $20^{\text {th }}$ century in urban area (Mukai et al., 1994). In Japan from 1980 s addition of $\mathrm{Pb}$ to gasoline was forbidden but still now main source of $\mathrm{Pb}$ is considered to be fuel even if other origins are taken into account (Legret and Pagotto, 1999). However, it is evident from Table $5 \mathrm{a}$ that the concentration of all trace metals studied, showed a wide range of variation between the minimum and maximum levels. Average $\mathrm{Br}$ concentration was about 18 times higher than its average shale value and in case of I it was about 5 times higher. Moreover, the trend of total $\mathrm{Br}$ and I concentration from Tokyo bay side to the upper side of the river was decreasing which may be due to the effect of mixing of tidal sea water with Tsurumi River water. Table $5 b$ represents a comparison of some trace metals and rare earth elements (REE) with average shale values and Japanese river sediment average. The mean concentration of Ba, Zr, Rb, Y, Sn, Sb, Cs, La, Ce, Pr and Nd were 374.4, 98.2, 53.705, 15.4, 10.7, 1.3, 4.6, 22.3, 45.1, 6.2 and $21.1 \mu \mathrm{g} / \mathrm{g}$, respectively. It is apparent from Table 5b that Ba, Zr, Rb, Y, Sn, Sb, Cs, La, Ce, Pr and Nd content in downstream of Tsurumi River was close to average shale values, as well as Japanese river sediment average values and there was no significant variation among the values which indicate that these elements were originated from lithogenic sources and anthropogenic

Table 4: General characteristics of sediment samples of Tsurumi River, Japan

\begin{tabular}{|c|c|c|c|c|c|c|c|}
\hline \multirow{2}{*}{ Sampling sites } & \multirow{2}{*}{$\mathrm{pH}$} & \multirow{2}{*}{$\mathrm{EC}(\mathrm{S} / \mathrm{m})$} & \multirow{2}{*}{ OC $(\%)$} & \multicolumn{3}{|c|}{ Particle size distribution } & \multirow{2}{*}{ Textural Classes } \\
\hline & & & & Clay (\%) & Silt (\%) & Sand (\%) & \\
\hline 1 & 8.35 & 0.441 & 6.3 & 29.5 & 34.3 & 36.2 & Clay loam \\
\hline 2 & 8.19 & 0.726 & 4.3 & 22.7 & 33.2 & 44.1 & Loam \\
\hline 4 & 8.35 & 1.256 & 6.2 & 16.2 & 34.5 & 49.3 & Loam \\
\hline 5 & 8.39 & 0.654 & 5.5 & 25.3 & 30.4 & 44.3 & Loam \\
\hline 6 & 7.43 & 1.075 & 4.6 & 40.8 & 29.5 & 29.7 & Clay \\
\hline 9 & 8.11 & 0.453 & 5.3 & 12.0 & 22.6 & 65.4 & Sandy loam \\
\hline 10 & 7.31 & 0.579 & 6.5 & 22.4 & 14.1 & 63.5 & Sandy clay loam \\
\hline 11 & 8.08 & 0.806 & 3.6 & 24.6 & 18.6 & 56.8 & Sandy clay loam \\
\hline 12 & 7.75 & 0.793 & 5.8 & 10.4 & 32.3 & 57.3 & Sandy loam \\
\hline 13 & 7.90 & 1.584 & 5.7 & 23.7 & 32.1 & 44.2 & Loam \\
\hline 18 & 7.22 & 0.502 & 0.4 & 7.4 & 17.9 & 74.7 & Sandy loam \\
\hline 19 & 6.75 & 0.207 & 0.3 & 3.7 & 19.0 & 77.3 & Loamy sand \\
\hline 20 & 7.19 & 0.147 & 0.4 & 4.7 & 12.5 & 82.8 & Loamy sand \\
\hline \multirow{2}{*}{ Range } & $6.54-$ & $0.147-$ & & $3.76-$ & 12.47- & $29.7-$ & \multirow{3}{*}{--- } \\
\hline & 8.39 & 1.584 & $0.3-6.5$ & 40.80 & 40.85 & 82.81 & \\
\hline Mean & 7.81 & 0.646 & 6.5 & 19.21 & 25.83 & 55.43 & \\
\hline
\end{tabular}


Int. J. Environ. Sci. Tech., 7 (1), 17-28, Winter 2010

Table 5a: Trace metal concentration $(\mu \mathrm{g} / \mathrm{g})$ in sediments of Tsurumi River, Japan

\begin{tabular}{|c|c|c|c|c|c|c|c|c|c|c|c|}
\hline $\begin{array}{l}\text { Sampling } \\
\text { sites }\end{array}$ & $\mathrm{Zn}$ & $\mathrm{Cu}$ & $\mathrm{Cd}$ & $\mathrm{Pb}$ & $\mathrm{Cr}$ & $\mathrm{V}$ & $\mathrm{Br}$ & I & As & $\mathrm{Ni}$ & $\mathrm{Sr}$ \\
\hline 1 & 461.4 & 222.6 & 0.9 & 51.5 & 117.4 & 147.5 & 113.6 & 20.4 & 14.1 & 39.4 & 193.1 \\
\hline 2 & 456.8 & 156.2 & 1.0 & 56.2 & 121.7 & 140.4 & 97.8 & 21.5 & 15.9 & 36.9 & 265.9 \\
\hline 3 & 493.8 & 167.1 & 0.9 & 49.0 & 108.7 & 193.7 & 114.6 & 12.6 & 13.5 & 41.4 & 141.4 \\
\hline 4 & 530.5 & 165.6 & 0.9 & 50.0 & 118.6 & 183.3 & 104.2 & 15.4 & 14 & 39.6 & 153.4 \\
\hline 5 & 476.4 & 163.5 & 0.9 & 48.2 & 108.9 & 198.1 & 103.0 & 13.2 & 13.2 & 38.8 & 147.6 \\
\hline 6 & 428.3 & 138.2 & 0.8 & 46.8 & 89.5 & 165 & 114.7 & 13.6 & 13 & 34.3 & 239.3 \\
\hline 7 & 327.7 & 108.7 & 0.7 & 34.1 & 91.6 & 137.2 & 61.9 & 10.2 & 9.7 & 31.1 & 172.5 \\
\hline 8 & 514.3 & 169.7 & 1.0 & 55.7 & 114.3 & 173 & 102.3 & 12.1 & 15.6 & 43.1 & 165.4 \\
\hline 9 & 429.2 & 146.8 & 0.6 & 42.6 & 111.3 & 207.4 & 83.9 & 13.3 & 11.3 & 39.8 & 142.8 \\
\hline 10 & 424.5 & 141.3 & 0.7 & 39.6 & 109.6 & 198 & 54.2 & 14.1 & 10.5 & 38.9 & 148.3 \\
\hline 11 & 362.1 & 119.2 & 0.6 & 36.9 & 114.5 & 190.7 & 73.2 & 9.1 & 9.3 & 37.4 & 156.4 \\
\hline 12 & 425.9 & 148.4 & 0.7 & 41.7 & 116.9 & 208.2 & 97.2 & 13.4 & 10.9 & 40 & 150.5 \\
\hline 13 & 492.4 & 175.9 & 1.1 & 59.4 & 104.8 & 194.3 & 86.1 & 6.8 & 16.5 & 47.3 & 152.6 \\
\hline 14 & 195.4 & 58.6 & 0.5 & 20.4 & 60.5 & 102.1 & 30.7 & 5.0 & 5.1 & 24.2 & 142.8 \\
\hline 15 & 322.8 & 91.9 & 0.7 & 28.9 & 78.9 & 140 & 41.6 & 7.7 & 7.6 & 31.5 & 164.7 \\
\hline 16 & 512.8 & 159.5 & 0.9 & 46.0 & 99 & 169.8 & 94.4 & 13.1 & 13 & 38.9 & 154.2 \\
\hline 17 & 414.5 & 229.9 & 5.7 & 74.5 & 252.7 & 208.5 & 40.2 & 3.3 & 21.7 & 57.5 & 140.6 \\
\hline 18 & 56.1 & 16 & 0.1 & 9.7 & 29.7 & 58.1 & 8.6 & 2.2 & 1.8 & 15.8 & 124.6 \\
\hline 19 & 126.9 & 33.3 & 0.4 & 12.7 & 44.4 & 88.1 & 5.2 & 2.2 & 1.9 & 25.1 & 167.1 \\
\hline 20 & 170.1 & 48.1 & 0.4 & 12.6 & 64.9 & 136.7 & 3.4 & 2.7 & 2.1 & 30.5 & 169.1 \\
\hline \multirow{2}{*}{ Range } & 56.1- & 16- & $0.1-$ & 9.7- & 29.7- & 58.1- & 3.4- & $2.2-$ & 1.8- & 15.8- & 124.6- \\
\hline & 530.5 & 229.9 & 5.7 & 74.5 & 252.7 & 208.5 & 114.7 & 21.5 & 21.7 & 57.5 & 265.9 \\
\hline Mean & 381.1 & 133.0 & 1.0 & 40.8 & 102.9 & 162.0 & 71.5 & 10.6 & 11.0 & 36.6 & 164.6 \\
\hline
\end{tabular}

Table 5b: Trace metal/REE concentration ( $\mu \mathrm{g} / \mathrm{g})$ in sediments of Tsurumi River, Japan

\begin{tabular}{|c|c|c|c|c|c|c|c|c|c|c|c|}
\hline Sampling sites & $\mathrm{Ba}$ & $\mathrm{Zr}$ & $\mathrm{Rb}$ & $\mathrm{Y}$ & Sn & $\mathrm{Sb}$ & Cs & $\mathrm{La}$ & $\mathrm{Ce}$ & $\operatorname{Pr}$ & $\mathrm{Nd}$ \\
\hline 1 & 317.6 & 100.0 & 53.4 & 15.5 & 12.5 & 1.1 & 4.2 & 22.2 & 45.7 & 6.3 & 20.5 \\
\hline 2 & 282.9 & 104.7 & 51.2 & 15.3 & 11.9 & 1.9 & 3.7 & 22.4 & 46.5 & 5.8 & 19.4 \\
\hline 3 & 286.7 & 95.9 & 49.4 & 18.9 & 10.4 & 1.3 & 3.3 & 19.0 & 39.8 & 4.5 & 18.0 \\
\hline 4 & 316.1 & 96.5 & 50.2 & 17.4 & 11.0 & 1.4 & 3.9 & 20.9 & 43.0 & 6.2 & 19.5 \\
\hline 5 & 297.8 & 96.7 & 50 & 18.3 & 11.0 & 1.3 & 3.8 & 20.3 & 42.8 & 5.8 & 19.3 \\
\hline 6 & 295.5 & 92.9 & 49.7 & 15.8 & 9.6 & 1.2 & 3.9 & 19.9 & 41.6 & 6.1 & 19.6 \\
\hline 7 & 411.0 & 100.7 & 55.6 & 14.3 & 8.0 & 1.3 & 5.2 & 23.1 & 47.9 & 7.0 & 22.2 \\
\hline 8 & 326.8 & 103.7 & 54.8 & 17.4 & 13.5 & 1.8 & 4.3 & 21.7 & 45.0 & 6.2 & 20.2 \\
\hline 9 & 363.1 & 99.4 & 49.3 & 18.1 & 9.0 & 1.5 & 4.2 & 20.8 & 43.4 & 5.9 & 21.4 \\
\hline 10 & 360.2 & 99.0 & 50.2 & 17.2 & 9.1 & 1.3 & 3.5 & 18.8 & 39.7 & 4.6 & 19.3 \\
\hline 11 & 377.6 & 116.6 & 55.3 & 16.9 & 8.6 & 1.4 & 5.0 & 23.3 & 48.2 & 7.1 & 23.2 \\
\hline 12 & 311.6 & 94.7 & 49.7 & 17.5 & 8.1 & 1.4 & 3.5 & 17.9 & 37.8 & 4.4 & 19.0 \\
\hline 13 & 303.9 & 100.4 & 54.7 & 19.3 & 13.2 & 1.7 & 4.6 & 41.2 & 77.4 & 8.4 & 26.4 \\
\hline 14 & 520.5 & 105.0 & 59.5 & 9.6 & 7.7 & 1.2 & 7.0 & 26.6 & 50.3 & 7.5 & 24.1 \\
\hline 15 & 462.0 & 105.9 & 59.6 & 12.6 & 10.8 & 1.4 & 5.6 & 26.2 & 51.5 & 7.1 & 24.1 \\
\hline 16 & 337.7 & 95.7 & 51.3 & 17.0 & 12.7 & 1.8 & 4.1 & 19.7 & 41.4 & 5.2 & 19.1 \\
\hline 17 & 386.4 & 106.8 & 62.4 & 18.8 & 37.3 & 1.1 & 4.5 & 21.4 & 45.5 & 6.0 & 22.3 \\
\hline 18 & 576.2 & 108.0 & 72.9 & 9.2 & 1.8 & 1.1 & 7.7 & 27.2 & 53.1 & 7.7 & 25.7 \\
\hline 19 & 489.2 & 69.4 & 49.1 & 8.7 & 4.9 & 0.8 & 5.6 & 17.2 & 31.1 & 6.8 & 19.0 \\
\hline 20 & 465.7 & 72.1 & 45.8 & 9.6 & 2.8 & 0.9 & 5.0 & 15.5 & 30.3 & 5.8 & 19.3 \\
\hline Range & $\begin{array}{r}282.9- \\
576.2\end{array}$ & $\begin{array}{r}69.4- \\
116.6\end{array}$ & $\begin{array}{r}45.8- \\
72.9\end{array}$ & $\begin{array}{r}8.7- \\
19.3\end{array}$ & $\begin{array}{l}1.8- \\
37.3\end{array}$ & $\begin{array}{c}0.8- \\
1.9\end{array}$ & $\begin{array}{r}3.3- \\
7.7\end{array}$ & $\begin{array}{l}15.5- \\
41.2\end{array}$ & $\begin{array}{l}30.3- \\
77.4\end{array}$ & $\begin{array}{r}4.4- \\
8.4\end{array}$ & $\begin{array}{l}18.0- \\
26.4\end{array}$ \\
\hline Mean & 374.4 & 98.2 & 53.705 & 15.4 & 10.7 & 1.3 & 4.6 & 22.3 & 45.1 & 6.2 & 21.1 \\
\hline $\begin{array}{l}\text { Average shale } \\
\text { (worldwide)* }\end{array}$ & 580 & 160 & 140 & 26 & 6 & 1.5 & 5 & 92 & 59 & 5.6 & 24 \\
\hline Japanese river sediment** & 408 & 56.2 & 69.7 & 18.1 & 2.43 & 0.699 & 3.95 & 17.2 & 32 & 4.08 & 16.4 \\
\hline
\end{tabular}


sources has less or no contribution to the enrichment of these metals.

\section{Relationship between analyzed parameters}

Correlation matrix for analyzed sediment parameters was calculated to see if some of the parameters were interrelated with each other and the results are presented in Tables 6. Examination of the matrix also provides clues about the carrier substances and the chemical association of trace metals in the study area (Forstner, 1981; Jaquet et al., 1982). Most of the physicochemical properties of sediments showed highly significant positive correlation with each other. Except Cd and Sr, all trace metals studied showed good to excellent positive correlation with \% OC of the sediments. This implies that the presence of organic matter has an influence on accumulation of trace metals in sediments of the downstream of the Tsurumi River. It is evident from Table 6 that majority of the trace metals show good correlation with each other, indicating a common source for these metals. However, Cd showed negative correlation with $\mathrm{Br}$, I and $\mathrm{Sr}$.

Comparative study of sediment samples of Tsurumi River with background and toxicological reference values

The available data for a comparative analysis with background and toxicological reference values for river sediments, along with average values obtained for trace metals of Tsurumi River sediments are summarized in Table 7. It is evident that the average total concentration of $\mathrm{Zn}, \mathrm{Cu}, \mathrm{Cd}, \mathrm{Pb}$ and $\mathrm{Cr}$ in sediments of Tsurumi River exceeded the geochemical background (shale standard and continental crust), as well as Japanese river sediment average, but the average concentration of As,
$\mathrm{Ni}$ and $\mathrm{Sr}$ are very close to Japanese river sediment average but lower than that of geochemical standard. However, when compared with effect-based toxicological levels (Table 7) the situation was also quite alarming for Tsurumi river sediments. The mean total concentrations of $\mathrm{Zn}, \mathrm{Cu}, \mathrm{Cd}, \mathrm{Pb}$ and $\mathrm{Cr}$ in sediments of the Tsurumi River were also higher than those of the Ministry of Environment (MOE), Japan's Environmental Quality Standard, (Japan EQS) Canadian Environmental Quality Guidelines (Canadian EQG), U.S. Environmental Protection Agency's (US EPA) toxicity reference values (TRV), Ontario Ministry of Environment's (Ontario MOE) lowest effect levels (LEL) and U.S. Department of Energy's (US DOE) threshold effect concentrations (TEC). The probable effect concentrations (PEC) and high no effect concentrations (HNEC) defined by the U.S. DOE and severe effect level (SEL) defined by the Ontario MOE for all studied trace metals presented in Table 7 were lower than the mean total concentrations of these elements except $\mathrm{Cu}$ in the sediments of Tsurumi River. The results indicate that the levels of trace metals found in the sediments of downstream of the Tsurumi River might create an adverse effects on the aquatic ecosystems associated with this river, especially after it receives urban water and wastewaters.

Assessments of anthropogenic pollution in sediments of Tsurumi River

Enrichment factors

Samples having EFc value greater than 5 are considered to be contaminated with that particular element. Fig. 2 represents the EFc values of all the trace metals measured in the sediment samples of the Tsurumi River. All the sampling sites have EFc values between 0-

Table 6: Correlation coefficient matrix between physico-chemical properties and trace metal concentrations of sediment samples

\begin{tabular}{|c|c|c|c|c|c|c|c|c|c|c|c|c|c|c|}
\hline & $\mathrm{pH}$ & EC & $\% \mathrm{OC}$ & $\mathrm{Zn}$ & $\mathrm{Cu}$ & $\mathrm{Cd}$ & $\mathrm{Pb}$ & $\mathrm{Cr}$ & $\mathrm{V}$ & $\mathrm{Br}$ & $\mathrm{I}$ & As & $\mathrm{Ni}$ & $\mathrm{Sr}$ \\
\hline $\mathrm{pH}$ & 1.000 & & & & & & & & & & & & & \\
\hline EC & 0.406 & 1.000 & & & & & & & & & & & & \\
\hline$\%$ OC & 0.467 & 0.468 & 1.000 & & & & & & & & & & & \\
\hline $\mathrm{Zn}$ & 0.527 & 0.503 & 0.949 & 1.000 & & & & & & & & & & \\
\hline $\mathrm{Cu}$ & 0.305 & 0.292 & 0.867 & 0.895 & 1.000 & & & & & & & & & \\
\hline $\mathrm{Cd}$ & -0.409 & -0.165 & 0.167 & 0.249 & 0.559 & 1.000 & & & & & & & & \\
\hline $\mathrm{Pb}$ & 0.229 & 0.381 & 0.796 & 0.874 & 0.956 & 0.635 & 1.000 & & & & & & & \\
\hline $\mathrm{Cr}$ & -0.094 & 0.010 & 0.531 & 0.595 & 0.816 & 0.885 & 0.845 & 1.000 & & & & & & \\
\hline V & 0.227 & 0.330 & 0.809 & 0.813 & 0.771 & 0.378 & 0.743 & 0.700 & 1.000 & & & & & \\
\hline $\mathrm{Br}$ & 0.652 & 0.534 & 0.867 & 0.894 & 0.760 & -0.012 & 0.717 & 0.347 & 0.624 & 1.000 & & & & \\
\hline I & 0.653 & 0.303 & 0.753 & 0.733 & 0.618 & -0.152 & 0.529 & 0.232 & 0.412 & 0.832 & 1.000 & & & \\
\hline As & 0.235 & 0.377 & 0.783 & 0.866 & 0.949 & 0.645 & 0.998 & 0.844 & 0.720 & 0.709 & 0.524 & 1.000 & & \\
\hline $\mathrm{Ni}$ & 0.058 & 0.241 & 0.734 & 0.796 & 0.902 & 0.693 & 0.913 & 0.894 & 0.864 & 0.536 & 0.321 & 0.898 & 1.000 & \\
\hline $\mathrm{Sr}$ & 0.147 & 0.161 & 0.069 & 0.190 & 0.147 & -0.087 & 0.207 & 0.007 & -0.111 & 0.329 & 0.530 & 0.209 & -0.009 & 1.000 \\
\hline
\end{tabular}

Note: $r$ values $>0.423,0.457,0.652$ denotes significant at 5.0, 1.0 and $0.1 \%$ level of probability, respectively 
Table 7: Comparative study of some potential trace metal of downstream sediment samples of the Tsurumi River with geochemical background and toxicological reference values for river sediments (mg/g)

\begin{tabular}{|c|c|c|c|c|c|c|c|c|c|c|c|c|c|}
\hline \multirow{2}{*}{$\begin{array}{l}\text { Trace } \\
\text { metal }\end{array}$} & \multicolumn{2}{|c|}{$\begin{array}{c}\text { Geochemical } \\
\text { background }\end{array}$} & \multicolumn{3}{|c|}{$\mathrm{US} \mathrm{DOE}^{\mathrm{c}}$} & \multicolumn{2}{|c|}{ Canadian EQG ${ }^{\mathrm{d}}$} & \multirow{2}{*}{$\begin{array}{c}\text { US } \\
\text { EPA }^{\mathrm{e}} \\
\text { TRV }\end{array}$} & \multicolumn{2}{|c|}{ Ontario $\mathrm{MOE}^{\mathrm{f}}$} & \multirow{2}{*}{$\begin{array}{c}\begin{array}{c}\text { Japan } \\
\text { MOE }^{\text {g }}\end{array} \\
\text { EQS }\end{array}$} & \multirow{2}{*}{ 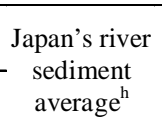 } & \multirow{2}{*}{$\begin{array}{l}\text { This study } \\
\text { (average) }\end{array}$} \\
\hline & $\begin{array}{c}\text { Shale } \\
\text { standard }^{\text {a }}\end{array}$ & $\begin{array}{c}\text { Continental } \\
\text { crust }^{\mathrm{b}}\end{array}$ & TEC & PEC & HNEC & ISQG & PEL & & LEL & SEL & & & \\
\hline $\mathrm{Zn}$ & 95 & 70 & 159 & 1532 & 541 & 123 & 315 & 110 & 120 & 820 & - & 118 & 381.1 \\
\hline $\mathrm{Cu}$ & 45 & 55 & 28 & 77.7 & 54.8 & 35.7 & 197 & 16 & 16 & 110 & 125 & 30.6 & 133.0 \\
\hline $\mathrm{Cd}$ & 0.30 & 0.20 & 0.59 & 11.7 & 41.1 & 0.6 & 3.5 & 0.60 & 0.60 & 10 & 1.0 & 0.158 & 1.0 \\
\hline $\mathrm{Pb}$ & 20 & 12.5 & 34.2 & 396 & 68.7 & 35 & 91.3 & 31 & 31 & 250 & $0.01 *$ & 23.1 & 40.8 \\
\hline $\mathrm{Cr}$ & 90 & 100 & 56 & 159 & 312 & 37.3 & 90 & 26 & 26 & 110 & - & 65.2 & 102.9 \\
\hline As & 13 & 1.8 & 12.1 & 57 & 92.9 & 5.9 & 17 & 6 & 6 & 33 & $0.01 *$ & 9.32 & 11.0 \\
\hline $\mathrm{Ni}$ & 68 & 75 & 39.6 & 38.5 & 37.9 & - & - & 16 & 16 & 75 & - & 25.1 & 36.6 \\
\hline $\mathrm{Sr}$ & 300 & 375 & - & - & - & - & - & - & - & - & - & 153 & 164.6 \\
\hline $\mathrm{Br}$ & 4 & 2.5 & - & - & - & - & - & - & - & - & - & - & 71.5 \\
\hline I & 2.2 & 0.5 & - & - & - & - & - & - & - & - & - & - & 10.6 \\
\hline V & 130 & 135 & - & - & - & - & - & - & - & - & - & 131 & 162 \\
\hline
\end{tabular}

Note: TEC $=$ Threshold effect concentration; PEC $=$ Probable effect concentration; HNEC $=$ High no effect concentration; ISQG $=$ Interim sediment quality guideline; PEL= Probable effect level; TRV= Toxicity reference value; LEL= Lowest effect level; SEL= Severe effect level; UP/SP= Unpolluted/ slightly polluted; EQS= Environmental quality standard and * means in solution.

${ }^{a}$ Turekian and Wedepohl (1961); ' ${ }^{\mathrm{b}}$ Taylor (1964); ' $\mathrm{Jones}$ et al. (1997); ${ }^{\mathrm{d} E n v i r o n m e n t ~ C a n a d a ~(2002) ; ~}{ }^{\mathrm{e}} \mathrm{US}$ EPA (1999); ${ }^{\mathrm{f} O M O E}$ (Ontario Ministry of Environment) (1993) and ${ }^{\mathrm{B}} \mathrm{MOE}$ - Japan (2004b) hamo (2007)

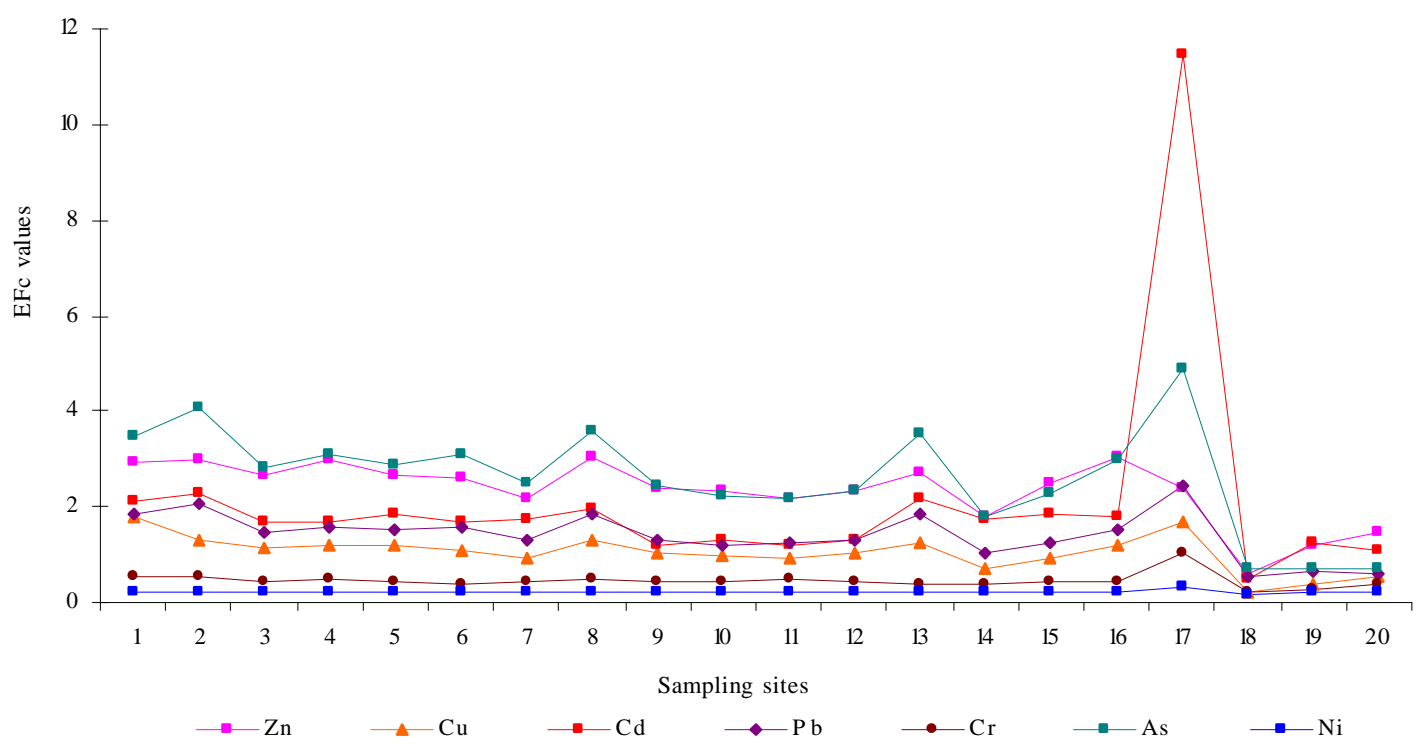

Fig. 2: EFc values of different sampling sites of the Tsurumi River, Japan

5 except Cd at sampling point 17. According to Atgin et al., (2000) these EFc values $(<5.0)$ have not been considered significant. However, As, $\mathrm{Zn}$ and Cd showed relatively higher enrichment values compared to other metals calculated. It is presumed that high EFc values indicate an anthropogenic source of trace metals, mainly from activities such as industrialization, urbanization, deposition of industrial wastes and others. Since, the bioavailability and toxicity of any trace metals in sediments depend upon the chemical form and concentration of the metals (Kwon et al., 2001), it can be inferred that trace metals in sediment samples with the highest EFc values, along with higher labile fractions in sediments are potential sources for mobility and bioavailability in the aquatic ecosystems.

\section{Index of geoaccumulation $\left(I_{\text {geo }}\right)$}

The calculated index of geoaccumulation $I_{\text {geo }}$ of the trace metals in the sediments of the Tsurumi River and their corresponding contamination intensity are illustrated in Fig. 3. The $I_{\text {geo }}$ values for $\mathrm{Cr}$, As, $\mathrm{Ni}$ and $\mathrm{Sr}$ exhibited a zero class, indicating unpolluted sediment 


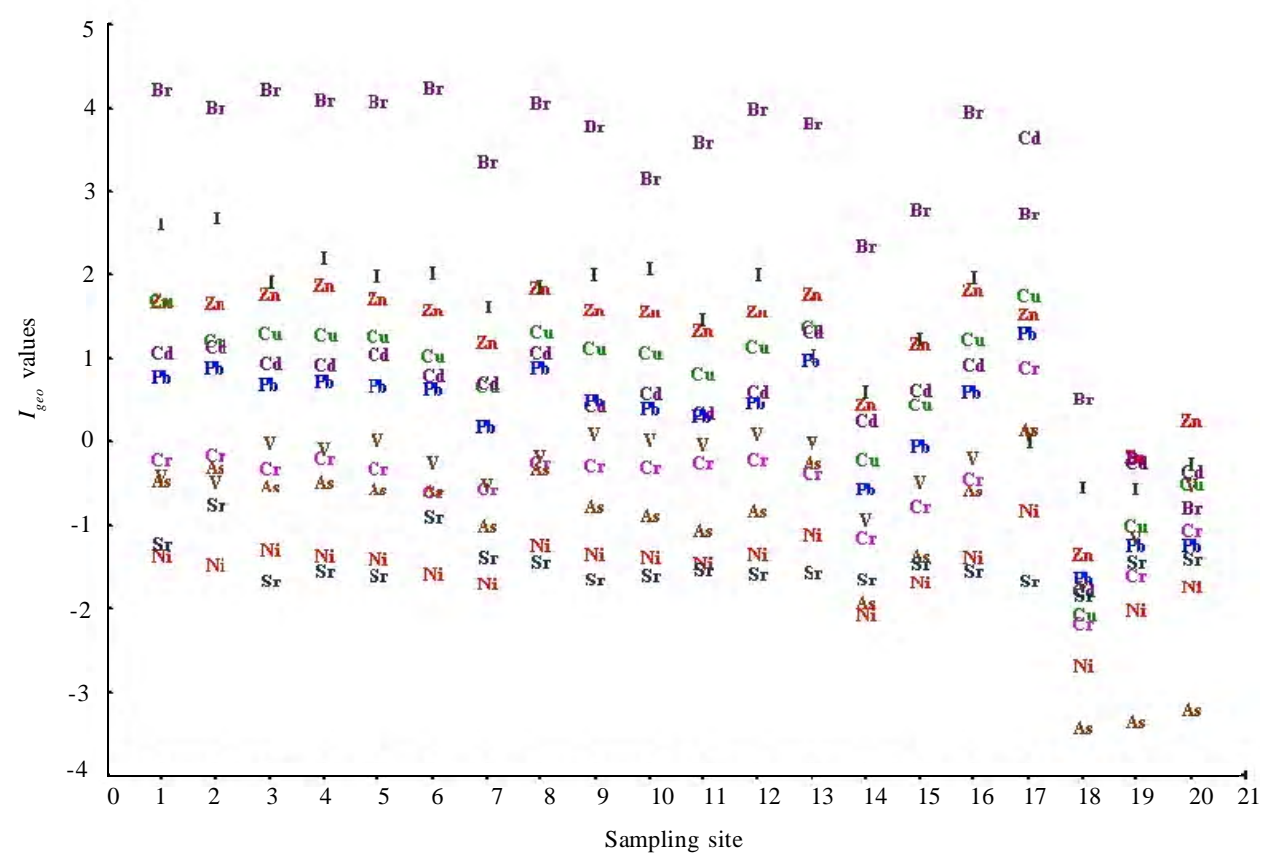

Fig. 3: $I_{\text {geo }}$ values of different sampling sites at Tsurumi River, Japan

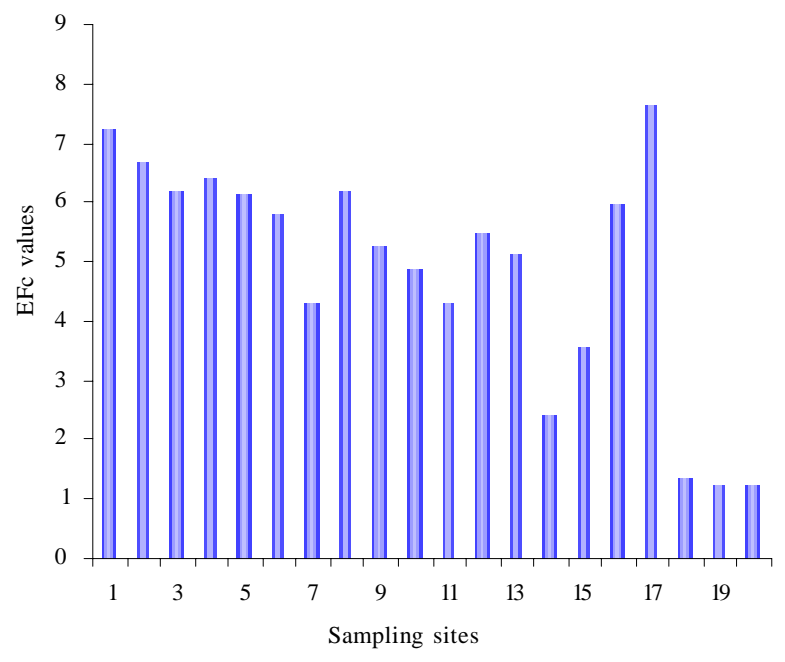

Fig. 4: PLI values of different sampling sites at Tsurumi River, Japan

quality. On the other hand, the values for $\mathrm{Zn}, \mathrm{Cu}$, $\mathrm{Cd}$, $\mathrm{Pb}, \mathrm{Br}$ and I (except at sampling sites 18, 19 and 20) exhibited class $0-4$, indicating moderately to heavily polluted sediment quality. However, Karbassi et al. (2008) mentioned that $I_{g e o}$ and EF failed to various degrees to indicate the intensity of pollution.
Pollution load index: A reflection of urbanization

The pollution load index as presented in Fig. 4 provides a simple, comparative means for assessing a site or estuarine quality: a value of zero $(0.0)$ indicates perfection, a value of one (1.0) indicate only baseline levels of pollutants present and values above one $>1.0$ ) would indicate progressive deterioration of the site and estuarine quality (Tomlinson et al., 1980). PLI values of sediments of the studied region ranged from 1.24-7.65 and the average was 4.88 which confirmed that the river sediments are polluted. However, the PLI of the zone or total area of the downstream of Tsurumi River was also high (6.53), indicating that $\mathrm{Zn}, \mathrm{Cu}, \mathrm{Cd}, \mathrm{Pb}$ and $\mathrm{Cr}$ were the major 5 pollutants. The PLI can provide some understanding to the public of the area about the quality of a component of their environment, and indicates the trend over time and area. In addition, it also provides valuable information and advice for the policy and decision makers on the pollution level of the area.

\section{CONCLUSION}

Trace metals in water and sediments of Tsurumi River downstream are either lithogenic or anthropogenic. This study revealed that enhanced concentrations of trace 
metals in most populated urban areas, as well as close to industrial establishments are due to strongly anthropogenic influences. The distribution pattern of trace metals in the river according to EFc and $I_{\text {geo }}$ index, the total area of the river studied has not yet been severely polluted but $\mathrm{Zn}, \mathrm{Cu}, \mathrm{Cd}, \mathrm{Pb}$ and $\mathrm{Cr}$ are enriched. However, the PLI values confirmed that the quality of water is deteriorating and this may have severe impact on marine livings and other organisms in the river.

\section{ACKNOWLEDGEMENTS}

The corresponding author thankfully acknowledges the Ministry of Education, Culture, Sports, Science and Technology, Japan, for financial support in the form of Monbukagakusho Scholarship.

\section{REFERENCES}

Abdel-Ghani, N. T.; Elchaghaby, G. A., (2007). Influence of operating conditions on the removal of $\mathrm{Cu}, \mathrm{Zn}, \mathrm{Cd}$ and $\mathrm{Pb}$ ions from wastewater by adsorption. Int. J. Environ. Sci. Tech., 4 (4), 451-456 (6 pages).

Abdel-Ghani, N. T.; Hefny, M.; El-Chaghaby, G. A. F., (2007). Removal of lead from aqueous solution using low cost abundantly available adsorbents. Int. J. Environ. Sci. Tech., 4 (1), 67-74 (8 pages).

Agbozu, I. E.; Ekweozor, I. K. E.; Opuene, K., (2007). Survey of heavy metals in the catfish synodontis clarias. Int. J. Environ. Sci. Tech., 4 (1), 93-98 (6 pages).

Akcay, H.; Oguz, A.; Karapire, C., (2003). Study of heavy metal pollution and speciation in Buyak Menderes and Gediz river sediments. Water Res., 37 (4), 813-822 (10 pages).

APHA, (1998). Standard methods for the examination of water and wastewater. $20^{\text {th. }}$ Ed., published jointly by American Public Health Association, American Water Works Association, Water Pollution Control Federation, Washington D.C.

Atgin, R. S.; El-Agha, O.; Zararsiz, A.; Kocatas, A.; Parlak, H.; Tuncel, G., (2000). Investigation of the sediment pollution in Izmir Bay: trace elements. Spectrochim. Acta B., 55 (7), 1151-1164 (14 pages).

Cenci, R. M.; Martin, J. M., (2004). Concentration and fate of trace metals in Mekong River Delta. Sci. Total Environ., 332 (1-3), 167-182 (16 pages)

Das, J. D.; Nolting, R. F., (1993). Distribution of trace metals in sediments and pore waters in the N.W. Mediterranean Sea. NIOZ, EROS-200 Project, 10.

Dassenakis, M.; Scoullos, M.; Foufa, E.; Krasakopoulou, E.; Pavlidou, A.; Kloukiniotou, M., (1998). Effects of multiple source pollution on a small Mediterranean River. Appl. Geochem., 13 (2), 197-211 (15 pages).

Environment Canada, (2002). Canadian sediment quality guidelines for the protection of aquatic life: Summary table. http: // www.doeal.gov/SWEIS / OtherDocuments / 328\%20envi\%20canada\%202002.pdf

Forstner, U., (1981). Metal pollution assessment from sediment analysis. in: Forstner, U. and Wittmann, G. T. W. (Eds.) Metal pollution in the aquatic environment. Springer, Berlin Heidelberg, New York, 486.
Gamo, T., (2007). Environmental geochemistry. (In Japanese) Baihu-kan, Japan, 118-119.

Harikumar, P. S.; Nasir, U. P.; Mujeebu Rahman, M. P., (2009). Distribution of heavy metals in the core sediments of a tropical wetland system. Int. J. Environ. Sci. Tech., 6 (2), 225-232 (8 pages).

Hobbelen, P. H. F.; Koolhaas, J. E.; van Gestel, C. A. M., (2004). Risk assessment of heavy metal pollution for detritivores in floodplain soils in the Biesbosch, the Netherlands, taking bioavailability into account. Environ. Pollut., 129 (3), 409 419 (11 pages).

Horowitz, A. J., (1991). A primer on sediment-trace element chemistry. $2^{\text {nd. }}$ Ed., Lewis Publishers, Chelsea (Michigan), 136.

Huheey, J. E., (1983). Inorganic chemistry: Principles of structure and reactivity. Harper and Row Publishers, New York, 912.

Islam, M. R.; Lahermo, W. P.; Salminen, R.; Rojstaczer, S.; Peuraniemi, V., (2000). Lake and reservoir water quality affected by metals leaching from tropical soils, Bangladesh. Environ. Geol., 39 (10), 1083 - 1089 (8 pages).

Jaquet, J. M.; Davaud, E.; Rapin, F.; Vernet, J. P., (1982). Basic concepts and associated statistical methodology in geochemical study of lake sediments. Hydrobiologia, 91 (1), 139 - 146 (8 pages).

Jones, D. S.; Sutter, I. I.; G. W.; Hull, R. N., (1997). Toxicological benchmarks for screening contaminants of potential concern for effects on sediment-associated biota: 1997 Revision, ES/ ER/TM-95/R4. Oak Ridge National Laboratory, prepared for the US Department of Energy. http://www.ornl.gov/ $\sim$ webworks/cpr/rpt/68667.pdf

Karbassi, A. R.; Monavari, S. M.; Bidhendi, G. R. N.; Nouri, J.; Nematpour, K., (2008). Metal pollution assessment of sediment and water in the Shur River. Environ. Monit. Assess., 147 (1-3), 107-116 (10 pages).

Khan, A. H.; Nolting, R. F.; Vander Gaast, S. J.; Van Raaphorst, W., (1992). Trace element geochemistry at the sediment water interface in the North Sea and the Western Wadden Sea. Netherlands Institute for Sea Research. NIOZ Report 1992-10. BARC Report 1992-1, BEON Report 18.

Kwon, Y. T.; Lee, C. W.; Ahn, B. Y., (2001). Sedimentation pattern and sediments bioavailability in a wastewater discharging area by sequential metal analysis. Microchem. J., 68 (2-3), 135-141 (7 pages).

Legret, M.; Pagotto, C., (1999). Evaluation of pollutant loadings in the runoff waters from a major rural highway. Sci. Total Environ., 235, 143-150 (8 pages).

Marin, A.; Lopez-Gonzalvez, A.; Barbas, C., (2001). Development and validation of extraction methods for determination of zinc and arsenic speciation in soils using focused ultrasound: Application to heavy metal study in mud and soils. Anal. Chim. Acta., 442 (2), 305-318 (14 pages).

Miller, C. V.; Foster, G. D.; Majedi, B. F., (2003). Baseflow and stormflow metal fluxes from two small agricultural catchments in the coastal plain of Chesapeake Bay Basin, United States. Appl. Geochem., 18 (4), 483-501 (19 pages).

Millero, F. J., (1974). The physical chemistry of seawater. Ann. Rev. Earth Planet. Sci., 2, 101-150 (50 pages).

MOE, (2004a). Ministry of Environment, Japan. Environmental quality standards for water pollution. Godochosha No. 5, 12-2 Kasumigaseki, Chiyoda-ku, Tokyo 100-8975, Japan. http://www.env.go.jp/en/water/wq/wp.pdf

MOE, (2004b). Ministry of Environment, Japan. Environmental 
quality standards for soil pollution. Godochosha No. 5, 1-2-2 Kasumigaseki, Chiyoda-ku, Tokyo 100-8975, Japan. http:// www.env.go.jp/en/water/soil/sp.html

Mukai, H.; Tanaka, A.; Fujii, T.; Nakao, M., (1994). Lead isotope ratios of airborne particulate matter as tracers of long-range transport of air pollutants around Japan. J. Geophys. Res., 99 (2), 3717-3726 (10 pages).

Muller, G., (1969). Index of geoaccumulation in sediments of the Rhine River. Geo. J., 2 (3), 108-118 (11 pages).

Muller, G., (1981). Die Schwermetallbelstung der sedimente des Neckars und seiner Nebenflusse: eine estandsaufnahme. Chem. Zeitung, 105, 157-164 (8 pages).

Nicolau, R.; Galera-Cunha, A.; Lucas, Y., (2006). Transfer of nutrients and labile metals from the continent to the sea by a small Mediterranean river. Chemosphere, 63 (3), 469-476 (8 pages).

Nito, S.; Kanno, Y.; Muto, A.; Uesugi, A.; Nakahama, T.; Inouye, Y., (2003). Biological evaluation of the pollution of the Tsurumi River with 7-Ethoxycoumario O-Deethylase activity induced by river sediment extracts in HepG2 cells. J. Health Sci., 49 (1), 8-12 (5 pages).

OMOE, (1993). Ontario Ministry of Environment, Guidelines for the protection and management of aquatic sediment quality in Ontario. Ontario Ministry of the Environment, Canada, 3 http://www.ene.gov.on.ca/envision/gp/B1-3.pdf

Omori, M.; Hatayama, Y.; Horiguchi, M., (Eds.), (1986). Geology

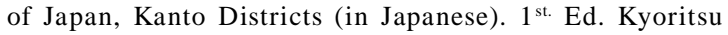
Publishing Co., Tokyo, Japan, 350.

Osmond, D. L.; Line, D. E.; Gale, J. A.; Gannon, R. W.; Knott, C. B.; Bartenhagen, K. A.; Turner, M. H.; Coffey, S. W.; Spooner, J.; Wells, J.; Walker, J. C.; Hargrove, L. L.; Foster, M. A.; Robillard, P. D.; Lehning, D. W., (1995). Water, Soil and Hydro-Environmental Decision Support System. http:// www.water.ncsu.edu/watersheds/info /hmetals.html

Sheikh, M. A.; Noah, N. M.; Tsuha, K.; Oomori, T., (2007). Occurrence of tributyltin compounds and characteristics of heavy metals. Int. J. Environ. Sci. Tech., 4 (1), 49-60 (12 pages).

Shrestha, R.; Fischer, R.; Sillanpaa, M., (2007). Investigations on different positions of electrodes and their effects on the distribution of $\mathrm{Cr}$ at the water sediment interface. Int. J. Environ. Sci. Tech., 4 (4), 413-420 (7 pages).
Sorme, L.; Lagerkvist, R., (2002). Sources of trace metals in urban wastewater in Stockholm. Sci. Total Environ., 298 (13), 131-145 (15 pages).

Stoeppler, M., (1991). Cadmium. in: Merian E. (Ed.), Metals and their compounds in the environment: Occurrence, analyses and biological relevance. VCH, New York. 803-851 (49 pages).

Taylor, S. R., (1964). Abundances of chemical elements in the continental crust: A new table. Geochim. Cosmochim. Acta., 28 (8), 1273-1285 (13 pages).

Tessier, A.; Campbell, P. G. C.; Bisson, M., (1979). Sequential extraction procedure for the speciation of particulate trace metals. Anal. Chem., 51 (7), 844-851 (8 pages).

Tomlinson, D. C.; Wilson, J. G.; Harris, C. R.; Jeffrey, D. W., (1980). Problems in the assessment of heavy-metal levels in estuaries and the formation of a pollution index. Helgoland Mar. Res., 33, 566-575 (8 pages).

Turekian, K. K.; Wedepohl, K. H. (1961). Distribution of the elements in some major units of the earth's crust. Geol. Soc. Am. Bull., 72, 175 - 192 (16 pages).

US EPA., (1989). U.S. Environmental Protection Agency. National Interim Primary Drinking Water Regulations. Code of Federal Regulations, Title 40, Parts 141 and 142

US EPA., (1999). U.S. Environmental Protection Agency. Screening level ecological risk assessment protocol for hazardous waste combustion facilities. Vol. 3, Appendix E: Toxicity reference values. EPA530-D99-001C. http:// www.epa.gov/epaoswer/hazwaste/combust/eco-risk/voume3/ appx-e.pdf

Walkley, A.; Black, I. A., (1934). An examination of the Degtjareff method for determining soil organic matter and a proposed modification of the chromic acid titration method. Soil Sci., 37, 29-38 (10 pages).

Wedepohl, K. H., (1969-1979). Handbook of geochemistry. Vols. I and II, Springer, Berlin Heidelberg, New York.

Zakir, H. M.; Sharmin, S.; Shikazono, N., (2006). Heavy metal pollution in water and sediments of Turag river at Tongi area of Bangladesh. Int. J. Lake River., 1 (1), 85-96 (12 pages).

Zvinowanda, C. M.; Okonkwo, J. O.; Shabalala, P. N.; Agyei, N. M., (2009). A novel adsorbent for heavy metal remediation in aqueous environments. Int. J. Environ. Sci. Tech., 6 (3), 425-434 (11 pages).

\footnotetext{
AUTHOR (S) BIOSKETCHES

Mohiuddin, K. M., Ph.D. Candidate, School of Science for Open and Environmental Systems, Faculty of Science and Technology, Keio University, Hiyoshi 3-14-1, Yokohama 223-8522, Japan and Assistant Professor, Department of Agricultural Chemistry, Bangladesh Agricultural University, Mymensingh - 2202, Bangladesh. Email: mohiagchem@gmail.com

Zakir, H. M., Ph.D., Associate Professor, Department of Agricultural Chemistry, Bangladesh Agricultural University, Mymensingh 2202, Bangladesh. Email: zakirhm.ac.bau@gmail.com

Otomo, K., Ph.D. Candidate, School of Science for Open and Environmental Systems, Faculty of Science and Technology, Keio University, Hiyoshi 3-14-1, Yokohama 223-8522, Japan. Email: k-otomo@dance.ocn.ne.jp

Sharmin, S., Ph.D. Candidate, School of Science for Open and Environmental Systems, Faculty of Science and Technology, Keio University, Hiyoshi 3-14-1, Yokohama 223-8522, Japan. Email: shl_sharmin@yahoo.com

Shikazono, N., Ph.D., Full Professor, Laboratory of Geochemistry, School of Science for Open and Environmental Systems, Faculty of Science and Technology, Keio University, Hiyoshi 3-14-1, Yokohama 223-8522, Japan. Email: sikazono@applc.keio.ac.jp 